- University, where the OPRR shut down federally funded research in December, citing numerous deficiencies in human subjects' protection. (The research is now being resumed.)

OPRR's investigation at the university was prompted by a complaint from Richard Curtin, a budget analyst at the US Department of Defense who is the father of college-age twins. One of them received a mailed questionnaire from Linda Corey, a professor of human genetics at the university, that solicited information for the Mid-Atlantic Twin Registry, a 20-year-old registry of 30,000 twin pairs used by medical researchers. The questionnaire asked about the occurrence of hundreds of medical conditions, including abnormal genitalia, alcoholism and infertility, in the twin and family members.

It was "a total invasion" of privacy, says Curtin, who adds that his security clearance at the Department of Defense could be revoked if he suffered from conditions such as mental illness.

"It appears that the [university ethics board] failed to consider the potential social, psychological, and legal risks" presented to twin subjects' family members by the collection of their detailed medical and social information without consent, OPRR wrote to university officials.

But in a letter in January, Collins told OPRR director Gary Ellis that he considered the presumption of risk to family members was unreasonable. "The OPRR's [position] represents a new policy that does not appear to have been informed by broad scientific or public input," he charged, adding that he has "deep concerns" about the decision.

Ellis, in a response to Collins on 22 February, said that OPRR had simply applied existing human subject protection regulations to a particular case, and not implemented a new policy or imposed new general rules.

"Please do not infer any general rulemaking by OPRR regarding informed consent from family members beyond the specifics of this particular research activity," said Ellis.

The American Society of Human Genetics (ASHG) and the National Institute for Child Health and Human Development have both contacted Ellis on the matter.

"We are very concerned about the fact that the collection of family history, which is a very important part of human genetics research, could be inhibited by too much control," says Uta Francke, the previous president of ASHG and a professor of genetics at Stanford University. Meredith Wadman

\title{
Panel will seek 'appropriate' AIDS goals for South Africa
}

\section{Cape Town}

South Africa's health department is setting up a panel of experts to tackle the AIDS epidemic, health minister Manto TshabalalaMsimang confirmed this week.

The panel of some 30 local and international experts will "explore all aspects of... developing prevention and treatment strategies that are appropriate to the African reality," she says in a press release.

The minister is hoping to reassure AIDS activists, who have accused the government of wilfully mismanaging the epidemic in South Africa, that the panel will be free to work to its own conclusions.

But she has not confirmed or denied the rumour that controversial biochemist Peter Duesberg of the University of California at Berkeley - who claims that the HIV virus is not the cause of AIDS - may be on the panel.

"Those with more extreme views are unlikely to participate because we are looking for a consensus," she says. AIDS activists continue to suspect that the government line supports the Duesberg claim.

The panel will review the general prevention and treatment (as well as the causes and diagnosis) of HIV/AIDS and opportunistic infections. It will also review the prevention of infection following rape or needle-stick injuries, and from mother to child.

The South African government recently refused to supply anti-retroviral drugs such as AZT to pregnant women within the state health system. It apparently believes that the

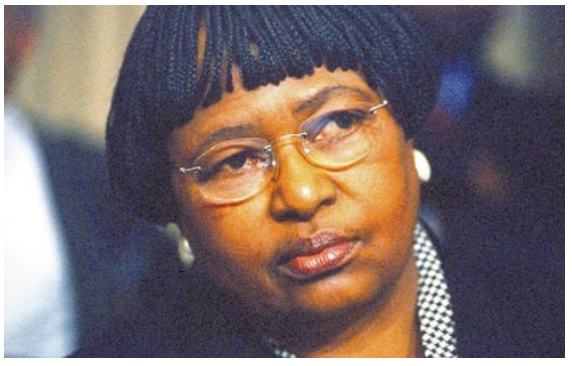

Tshabalala-Msimang: 'no hidden agendas'.

risks of using the drugs outweigh the benefits, despite advice to the contrary from different expert groups (see Nature 403, 692; 2000). Tshabalala-Msimang says this decision could be reconsidered if the panel convincingly shows that treatment would be effective. But an "ingenious solution" to the difficulties of financing the treatment would need to be found in such a case, she says.

Tshabalala-Msimang denies claims by the Treatment Action Campaign (TAC) that the panel is "a justification for the immoral, unscientific and unlawful decision" not to give the drugs to pregnant women. "I hope the work of the panel will demonstrate that we have no hidden agendas," she says.

The TAC has challenged the minister and her advisers to publish evidence from any scientific study to prove that provision of AZT is not economically feasible in South Africa, or that AZT is toxic to mother or child when given to women in the last trimester of pregnancy. Michael Cherry

\section{\$350m gift boosts MIT brain power}

\section{Boston}

The Massachusetts Institute of Technology has a bold plan to make itself a world leader in neuroscience. Last week, MIT announced the creation of an ambitious institute to study the human brain.

It will be the centrepiece of a new neuroscience complex, scheduled for completion in 2004. The McGovern Institute for Brain Research will be joined in the complex by an expanded version of MIT's Center for Learning and Memory (CLM) and a $\$ 20$ million centre for brain imaging. "With all the resources here, MIT should stand among the best in this field," says MIT molecular biologist Phillip Sharp, who will direct the institute.

Patrick McGovern, founder of computer publishing giant the International Data Group, and his wife Lore Harp McGovern, a high-tech entrepreneur, will give $\mathbf{\$ 3 5 0}$ million over 20 years - the largest gift ever pledged to a US university. They picked MIT, from which Patrick McGovern graduated in 1959 , because of its reputation for fostering interdisciplinary research.

The McGovern Institute will house 16 labs and 300 staff. Its model is theWhitehead Institute for Biomedical Research, also at MIT, where Lore Harp McGovern chairs the Board of Associates and her husband is a trustee. "I was impressed with how much progress they've made, for example, in understanding the causes of cancer and other diseases," says Patrick McGovern. "It shows what can be done at a missionoriented centre if you bring the right people together."

For Sharp, who won the Nobel prize in medicine in 1993 for his work on RNA 


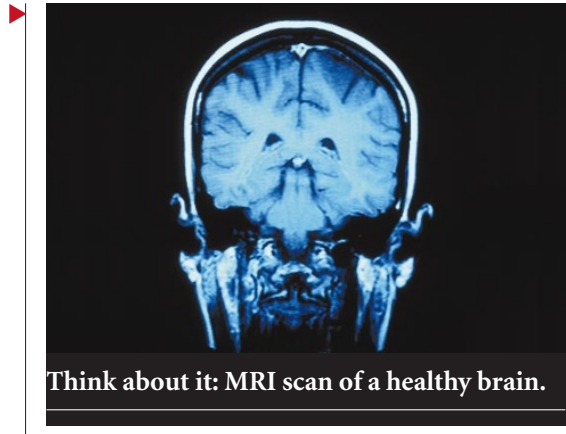

splicing, the move into neuroscience is a shift in direction. "This field is ready for rapid advance," he says. Brain imaging techniques, tools from molecular biology and genetics, insights from the Human Genome Project, and increasing computer power offer huge potential, he says. "The challenge now is to put together a first-rate programme." $\mathrm{He}$ expects the centre to be fully developed within about 10 years.

Sharp is working with Tomaso Poggio, an MIT computational neuroscientist, to chart future research directions. "We will have several years, if not longer, to make decisions about the range of programmes," Sharp says.

The complex will also include the $\$ 20$ million Martinos Imaging Center and the CLM. The imaging centre, to be shared with Harvard University and Harvard Medical School, will work on technologies such as magnetic resonance imaging (MRI), positron emission tomography, and optical imaging. "The idea is to use our technical prowess to advance these tools even further," says Mriganka Sur, who chairs MIT's Department of Brain and Cognitive Sciences.

The CLM, headed by MIT Nobel laureate Susumu Tonegawa, has seven investigators, with five more staff to be hired. It receives about half its funding, US\$3.5 million per year, from the RIKEN Institute, a Japanese government agency - a figure expected to grow to US $\$ 5$ million. Tonegawa predicts that the CLM and the McGovern Institute, working side by side, "will become a major force in neuroscience".

The trick now is figuring out how to make the various pieces fit together. The tentative plan is for the CLM, which investigates learning, memory and neuroplasticity, to continue its emphasis on molecular- and cellular-level processes, while the McGovern will focus on higher-level functions, such as information processing in the brain.

"We want enough overlap so we can interact without duplicating each other's efforts," says Sharp. "It's easy to identify broad themes of what we'd like to see emerge. But we won't know the specifics until we do the work." Steve Nadis

\section{Indian research budget favours defence}

\section{New Delhi}

The Indian government has kept its promise to significantly boost the national research budget — but the main beneficiary will be the military.

The recent clash with Pakistan in the Kargil area of the Himalayas, which exposed India's weakness in satellite surveillance and mountain warfare, lies behind the preferential funding increases for military-related research.

Military research now absorbs more than half of the research budget, which, at 120,654 million rupees (US $\$ 2.8$ billion), is nearly 20 per cent up on last year (see table).

A large chunk of the additional funding will be used to develop and build five remotesensing satellites, three of which will be high resolution. Although the government claims that these satellites are intended for both military and civilian applications, sources within the science ministry say their main application will be military.

The defence services had been demanding dedicated satellites for surveillance for some time, says Uday Bhaskar, deputy director of the Institute for Defence Studies and Analysis in New Delhi, adding that the Kargil conflict seems to have clinched it.

The Department of Atomic Energy intends to use part of its additional 2,270 million rupees to develop intense electronbeam machines that can potentially knock out enemy missiles.

It will also use some of the new funds to develop a 500-MW prototype fast breeder reactor which will use plutonium produced by Indian power reactors.

Science secretary Valangiman Ramamurthi says that, although more military research is needed for national security, the scientific community in general is "quite happy" with the budget. "Allocations for almost all science departments have gone up

\begin{tabular}{|lcc|}
\hline \multicolumn{3}{|c|}{ Table: Indian science budget (in million rupees) } \\
\hline \multirow{2}{*}{ Defence } & 1999 & 2000 \\
\hline Space & 20,954 & 22,742 \\
\hline Atomic energy & 17,259 & 20,192 \\
\hline Agriculture & 13,791 & 16,079 \\
\hline Industrial & 13,040 & 14,046 \\
\hline Environment & 8,237 & 9,704 \\
\hline Dept of S\&T & 7,180 & 9,650 \\
\hline Medical & 6,173 & 7,798 \\
\hline Non-conventional energy & 7,519 & 9,139 \\
\hline Information technology & 3,195 & 4,443 \\
\hline Oceanography & 1,950 & 3,920 \\
\hline Biotechnology & 1,067 & 1,580 \\
\hline Total & 1,282 & 1,361 \\
\hline
\end{tabular}

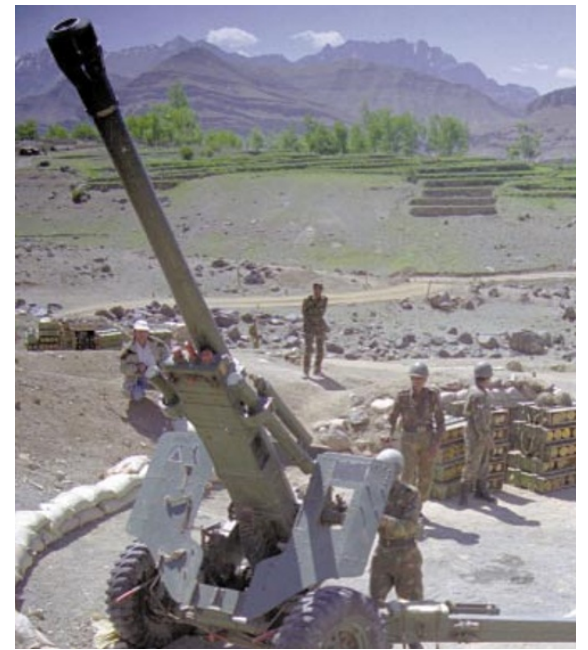

Going great guns: the Indian militia in Kargil.

between 14 and 20 per cent compared to last year," he says.

"Basic research did not get as much as we wanted," he admits, but the government has allocated additional funds for the two new research centres - the National Brain Research Centre (500 million rupees) and the National Centre for Plant Genome Research (350 million rupees), both in New Delhi.

Ramamurthi is particularly happy that 500 million rupees has been earmarked for some of the technology projects identified in the Vision-2020 document prepared in 1997 by the Technology Information Forecasting and Assessment Council, a governmentindustry think-tank. "The money for this has come at the right time," he says. Projects such as the use of fly ash (a waste product from coal-based power stations) as building material and the development of hydrogen as an energy source will now be taken up seriously, he says.

The science budget also provides 500 million rupees for launching the New Millennium Indian Technology Leadership Initiative. Ragunath Mashelkar, secretary to the Department of Scientific and Industrial Research, says this initiative will "focus on four or five areas which would fulfil the national objectives of a global leadership in technology". The government, industry and venture capitalists will team up to accomplish this, he says.

India's 200 patent offices will receive 750 million rupees for modernization. Scientists have particularly welcomed the announcement that universities and research institutes can keep all the royalties earned from patents, amending existing rules requiring patent holders to share royalties with agencies that funded their research. K. S. Jayaraman 